\title{
組合せ荷重を受けるケーソンー捨石マウンド系の破壊曲面
}

Failure locus of a caisson-rubble mound system subject to combined loads 小林俊一*・関口秀雄* - J. A. M. Teunissen ${ }^{\dagger}$ Shun-ichi Kobayashi, Hideo Sekiguchi \& J. A. M. Teunissen Stability of a composite breakwater which consists of a caisson and a rubble mound is discussed. Stability against sliding is conventionally estimated by the following formula, $H=\tan \delta \cdot V$ where $V, H$ and $\tan \delta$ are vertical load, horizontal resistance force and apparent friction angle between a caisson and a rubble mound. The value of $\tan \delta$ used for design is 0.6 which is an empirical constant. From geotechnical point of view, this stability problem is equivalent to a bearing capacity problem of a shallow foundation subject to combined loads. By introducing macroscopic failure locus of a cassion-rubble mound system in 3-dimensional load space $V-H-M / B$, it can be easily explain that $\tan \delta$ depends on loading conditions. Non-linear FE analysis is performed to evaluate a bearing capacity characteristic. The numerical results show that $\tan \delta$ reduces owing to existence of a moment load around a base of a caisson. For breakwater problems, a horizontal component of wave loads also cause moment loads because they are working at some heights from the base. The importance of an applied height of a horizontal load is highlighted for rational estimation of sliding resistance of the breakwater system.

Keywords : Sliding, bearing capacity, apparent friction angle, macroscopic failure locus

1.はじめに

わが国の防波堤はケーソン式混成堤がその主流を占めている。ケーソン式混成堤の安定性を照査するためには、 下部の捨石マウンドと上部のケーソン躯体の滑動および転倒に対する検討が必要であることは言うまでもない。 従来、滑動に対する安定性の検討は、作用波力と搭石マウンドーケーソン間の摩擦抵抗力を考慮した、水平方向の 力の釣合から求められてきた。このうち摩擦抵抗力については、見かけの摩擦係数 $\tan \delta=0.6$ として評価を行っ ているのが実情である。この值は経験的に知られてきたもので、実務上にも有用であるが、物理的な根拠に乏し い。本研究では地盤工学の視点から、波力を受けるケーソン式混成堤の安定性の問題を “組合せ荷重を受ける浅 い基礎の支持力問題”と位置づけ、その支持力特性を荷重空間におけるマクロな破壊曲面で表現し、さまざまな 荷重条件におけるケーソン式混成堤の安定性の合理的な評価を試みる。

\section{2. マクロな破壊曲面による浅い基礎の支持力特性の表現}

(a)一般的考察 さまざまな荷重条件における基礎の支持力特性を扱うためには、支持力特性を closed form で表 現できる方が見通しが良い。しかしながら、一般的に支持力問題の理論解を closed form で得ることは困難であ る。そのため、ここでは実験解に基づく closed form の実験式として、表現の簡便な Nova et al.の実験式 [1] を 用いて議論を進めることにする。

Nova et al. は $1 \mathrm{~g}$ 場において、砂質地盤上の浅い基礎に傾斜荷重および偏心荷重を載荷する支持力実験を行い、 結果を鈶直荷重 $V$ 、水平荷重 $H$ およびモーメント荷重 $M / B$ からなる 3 次元荷重空間内のマクロな破壊曲面とし て次式で表現した。

$$
\begin{aligned}
& h^{2}+m^{2}-\xi^{2}(1-\xi)^{2 \beta}=0 \\
& \xi=V / V_{M} ; h=H /\left(\mu V_{M}\right) ; m=M /\left(\psi B V_{M}\right)
\end{aligned}
$$

このマクロな破壊曲面をスケッチしたものが図 1 である。 $\mu$ 、 $\psi$ はそれぞれマクロな破壊曲面を $V-H$ 面あるいは $V-M / B$ 面で切った断面の原点における傾きで

$$
\mu=\left.\frac{d H}{d V}\right|_{V=0, M=0} \quad \psi=\left.\frac{d M}{B d V}\right|_{V=0, H=0}
$$

- 正会員 京都大学工学部土木工学科 ( $\bar{T} 606$ 京都市左京区吉田本町)

排会員 Delft Geotechnics 
である。 $\beta$ は $H_{m a v}$ が発揮される $V$ の値を決めるパラメータで、 $\beta=1$ であれば $H_{m a v}$ は $V=0.5 V_{\text {mav }}$ の時に発揮 されることになる。

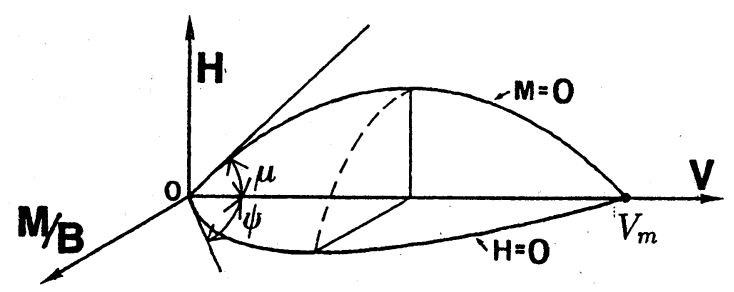

図1. 浅い基礎のマクロな破壊曲面

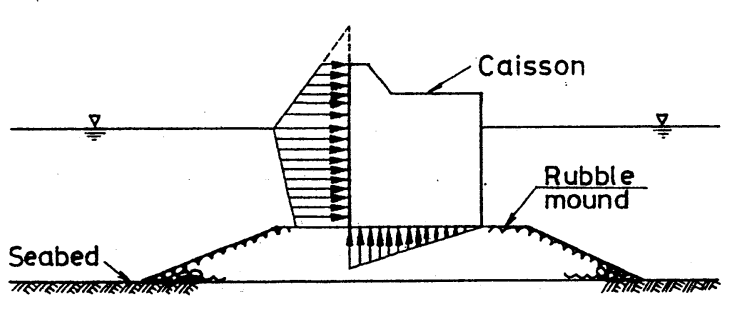

図 2. ケーソン式混成堤に作用する外力

(b) ケーソン式混成是への適用 ケーソン式混成堤に作用する外力としては、図 2 に示す波力と揚圧力を考虑す る。まずこれらを集中荷重に置き換え、図 3 に示す単純化を行う。ここで波力による水平荷重 $H$ ガケーソン底面 から $l_{H}$ の位置に作用すること、揚圧力およびケーソンの水中重量による鉛直荷重 $V$ が底面中央から偏心量 $e_{\boldsymbol{c}}$ の位 置に作用することを考虑すると、底面中央回りには

$$
\frac{M}{B}=\frac{e_{c}}{B} \cdot V+\frac{l_{H}}{B} \cdot H
$$

なるモーメント荷重が生じていることが理解される。式 3 を式 1 に代入すると、マクロな破壊曲面は $V-H$ 面上 に投影され

$$
h=\xi\left\{-\frac{\bar{e} \cdot \bar{l}}{1+\bar{l}^{2}}+\sqrt{\frac{(1-\xi)^{2 \beta}}{1+\bar{l}^{2}}-\left(\frac{\bar{e}}{1+\bar{l}^{2}}\right)}\right\}
$$

と表される。ここにI、悄それぞれ

$$
\bar{l}=\frac{\mu \cdot l_{H}}{\psi B}, \bar{e}=\frac{e_{c}}{\psi B}
$$

と定義される無次元量である。

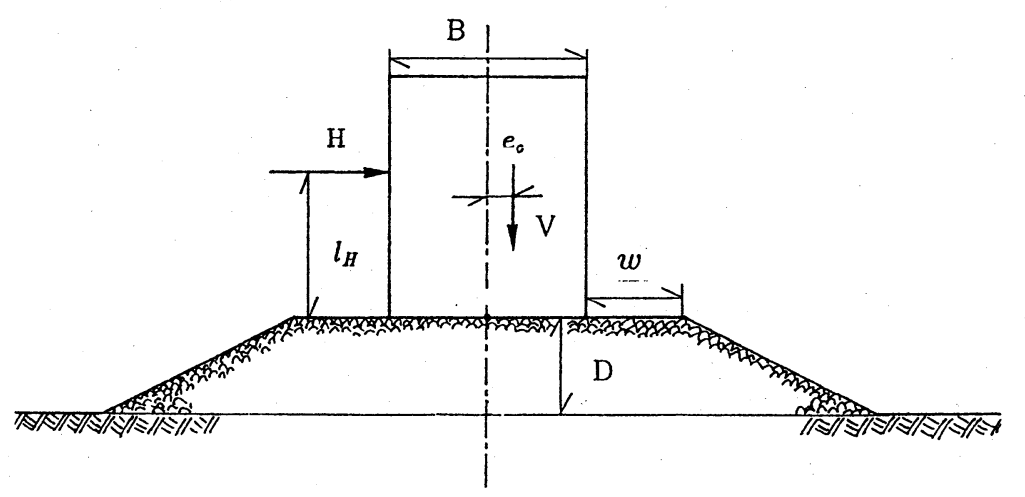

図 3. ケーソン式混成堤に作用する外力の単純化

従来の設計で用いられている “見かけの摩擦係数 $\tan \delta ”$ はこの $V-H$ 面に投影されたマクロな破壊曲面の割線勾 配を表していることになる。この式から、同一の鉛直荷重が載荷されているとき $(\xi=$ const. $)$ に、水平力作用高 さが増加すれば $l_{H}$ が大きくなり、発揮される水平支持力 $h$ は減少することがわかる。したがって割線勾配も小さ くなる。つまり水平力作用高さによって見かけの摩擦係数は低下する。また曲線は原点を通り、上に凸であるこ とから、鉛直荷重が増加しても割線勾配が低下することがわかる。

以上のように見かけの摩擦係数 $\tan \delta$ は荷重条件によってその值を大きく異にする。そこで混成堤に作用する荷 重条件について検討を行う。一般的に鈆直荷重レベルは捨石マウンドの鉛直極限支持力よりも十分小さい。した がって、捨石マウンドーケーソン来の荷重状態はマクロな破壊曲面の原点側の部分にあると考えて良い。また揚圧 力はケーソンの水中重量に比べるとかなり小さいので、鉛直荷重の偏心によって生じるモーメント荷重は小さい と考えられる。一方、水平荷重については、合田式を援用した図 2 の波圧力分布からも容易に想像できるように、 ケーソン幅とほぼ同じオーダーの水平力作用高さを有した水平荷重が作用しており、底面にはかなり大きなモ一 メント荷重が生じていると考えられる。このことから、ケーソン部の滑動安定性を検討する場合、水平力作用高 さによる“見かけの摩擦係数” の低下を十分に考慮する必要があることがわかる。 
3. 破壊曲面の同定

(a) 拮石マウンドの支持力実験 これまでの Frameworkをもとに、実際の防波堤の滑動安定性を評価するために は、唅石マウンドーケーソン系の支持力特性を具体的に把握しなければならない。原位置における捨石マウンドー ケーソン系の支持力実験は、陸上でほぼ実物に近い規模の実験マウンドを築造し支持力特性を求めた田中らの実 験例 [2] を除いては、あまり行われていないようである。同実験では、幾何条件としてマウンド厚 $D=2[m]$ の 実験マウンド上に、屃幅 $w=3[\mathrm{~m}]$ となるように幅 $B=3[\mathrm{~m}]$ のブロックを設置した。荷重条件は偏心のない一定 の鉛直荷重を載荷した状態で、2通りの水平力作用高さ $l_{H}=0.55,1.50[\mathrm{~m}]$ とした水平荷重を載荷している。

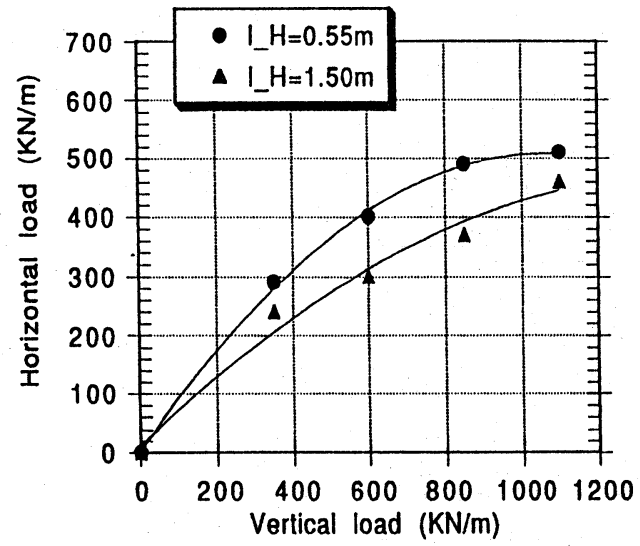

表 1. 解析に用いたパラメータ

\begin{tabular}{||l|c|c|c||}
\hline & Unit & Mound & Caisson \\
\hline \hline Young's Modulus & {$\left[\mathrm{KN} / \mathrm{m}^{2}\right]$} & $2.5 \times 10^{5}$ & $2.5 \times 10^{10}$ \\
\hline Poisson's ratio & - & 0.3 & 0.3 \\
\hline Friction angle & {$[D e g]$.} & $30^{\circ}$ & - \\
\hline Dilatancy angle & {$[D e g]$.} & $0^{\circ}$ & - \\
\hline Cohesion & {$\left[K N / \mathrm{m}^{2}\right]$} & 5.0 & - \\
\hline Unit weight & {$\left[\mathrm{KN} / \mathrm{m}^{3}\right]$} & 18.0 & 0.0 \\
\hline
\end{tabular}

図 4. 田中らによる支持力実験の結果

この実験結果（図 4）からマクロな破壊曲面のパラメ்ータを同定すれば、 $V_{\text {mav }}=2400[K N / m] 、 \mu \approx 0.97$ 、 $\psi \approx 0.43 、 \beta=1.0$ が得られる [3]。以下では同実験を参考に、非線形有限要素法 [4] によって支持力特性を評価 する。

(b) 有限要素法による解析 まず、地盤は非関連流れ則に従う弾完全塑性 Mohr-Coulomb 材料であると仮定した。 ケーソンは地盤よりも十分に大きな剛性を有する弾性体とし、その底面は完全に粗とした。解析に使用した材料 パラメータを表 1 に示す。解析に使用したメッシュは図 5 で、厚さ $D=2[m]$ の水平地盤上に自重を無視した幅 $B=3[m]$ ケーソン構造物を設置している。解析は荷重制御条件で行い、ケーソンの上面に鉛直力および水平力 を等分布荷重として作用させた。境界条件として両端はスライダー、下端は完全拘束とした。実際の実験マウン ドは斜面を有するが、混成堤を対象とした低い鈆直荷重レベルの解析を行うので、斜面に上る支持力特性の变化 は無視できると考え、解析では水平地盤を対象としている。

非線形計算は、各增分ステップに対して力の釣合のアンバランスが $0.5 \%$ 以下となるように反復計算を行い、解 が収束しなくなったところで支持力破壊が生じたとみなした。ただし一般に Newton 法は大域的収束性を有さな いので、荷重増分ステップが大きすぎることによって解が発散することもある。そこで各解析後、荷重 変位曲 線の形状をチェックし、荷重增分ステップが適当であったことを確認している。また極限荷重を精度よく求める． ため、9節点のアイソパラメトリック 2 次要素を使用した [5]。

(c) 鉛直支持力解析結果 予備的な解析として趽直極限支持力の解析を行った。その結果 $V_{M} \approx 2100[\mathrm{KN} / \mathrm{m}]$ を

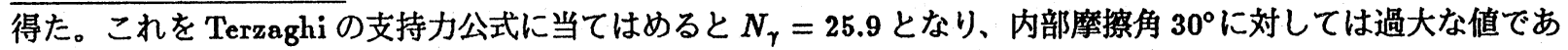
る。一方、幾何条件を变え、十分な層厚と両端境界までの距離を確保した別の解析例では、 $N_{\gamma}=15.4$ となる。こ れらから図 5 のメッシュを用いた解析では、地盤層厚が浅いため地盤底面の境界の剛性が支持力に反映されてい る可能性や両端の拘束条件が効いている可能性がある。

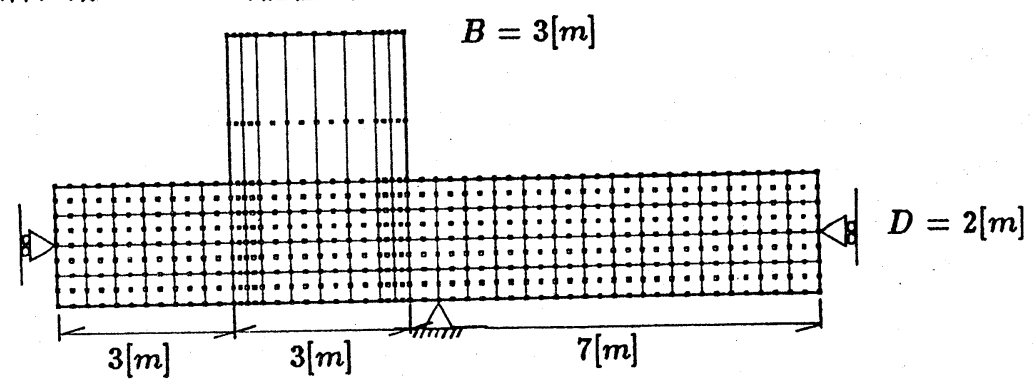

図 5. 有限要素解析に用いたメッシュ 
(d) 組合せ荷重下の支持力解析結果 水平力作用高さをそれぞれ $l_{H}=0.5,1.5,2.5,5.0[\mathrm{~m}]$ とした場合の解析結 果を図 6 に示す。これらの解析では荷重経路として、まず所定の鈆直荷重に達するまで鉛直荷重のみを単調に載 荷し、次いで趴直荷重を一定に保ったまま、水平荷重を一方向に単調に負荷していく経路をとった。数值解析結 果は、水平力載荷高さの増加や鉛直荷重の増加に伴う見かけの摩擦保数の低下を定性的によく表している。しか し原位置実験結果と定量的には一致せず、特に水平方向の支持力は実験結果の約 $50 \%$ 程度しか発揮されていない。 この理由として捨石マウンド材の内部摩擦角が $30^{\circ}$ よりも大きいことや、ダイラタンシー角がゼロではないことが 考えられる。特に、ダイラタンシー角は鉛直支持力にはほとんど影響を及ぼさないが [6]、本解析のように鉛直荷 重レベルが低く、単純せん断モードが卓越する場合には大きな水平支持力を発揮すると考えられる（付録参炤）。

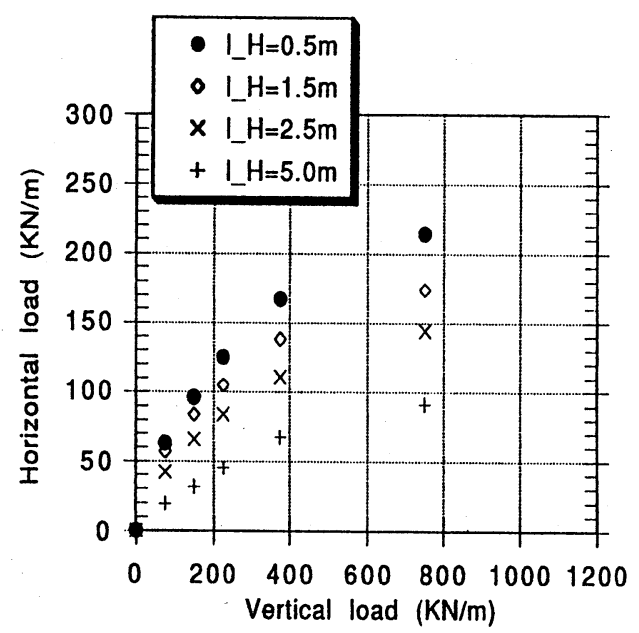

図 6. FEM による解析結果

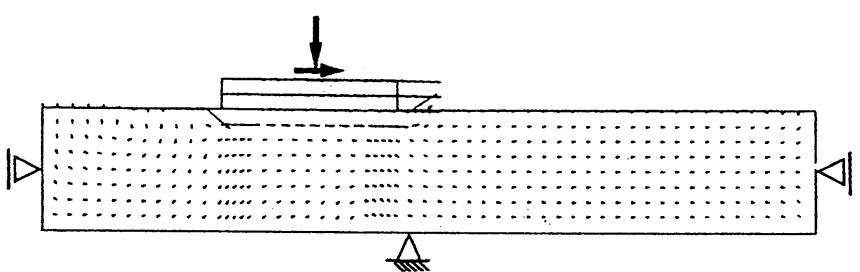

図 7. 滑動が卓越した破壊モード $\left(l_{H} \doteq 0.5[m]\right)$

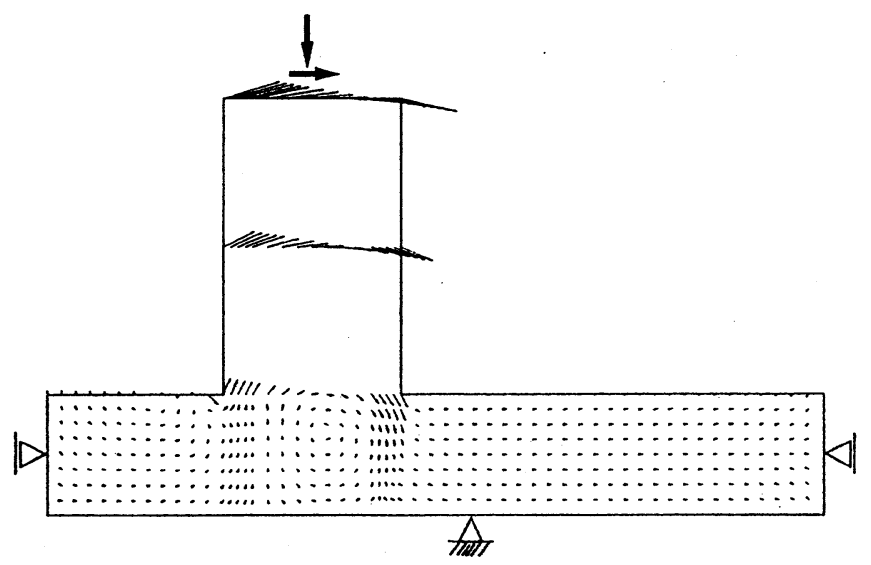

図 8. 転倒が卓越した破壊モード $\left(l_{H}=5.0[m]\right)$

破壊モードの例を図 $7 、 8$ に示す。図 7 は水平力作用高さが $l_{H}=0.5[\mathrm{~m}]$ のケースで、典型的な滑動モードが生じ ており、ケーソンがほとんど水平方向に滑動している様子が見られる。一方、図 8 は水平力作用高さが $l_{H}=5.0[m]$ のケースで典型的な転倒モードが生じ、底面部に明瞭な回転中心が見られる。

これらの解析結果をもとにマクロな破壊曲面のパラメータの同定を行う。まず、鈆值荷重の偏心量が $e_{c}=0 よ$ り、式 4 は

$$
h=\xi \frac{(1-\xi)^{\beta}}{\sqrt{1+l^{2}}}
$$

となる。パラメータ $\beta$ は最大水平抵抗力 $H_{\text {max }}$ が発揮されるときの鈶直荷重 $V=V_{M} /(1+\beta)$ となることから推定 できる。本解析ではほぼ $V \approx 700[K N / m] て ゙ ~ H_{\text {max }}$ が発揮されているので、 $\beta \approx 2.0$ となる。しかしこの值は地 盤下部の剛な境界の影響が大きく出ていると考えられ、下部の境界の影響のあまり出ない鈆直荷重レベルの低い 領域を表現するのには適当ではないと考えられる。そこで通常よく用いられる $\beta=1$ を仮定する。式 6 より、鉛 直荷重が等しく、水平力作用高さの異なるケースを取り上げると、

$$
\frac{h\left(l_{H}=0.5[m]\right)}{h\left(l_{H}=2.5[m]\right)}=\sqrt{\frac{1+(\mu / \psi)^{2}(2.5 / 3.0)^{2}}{1+(\mu / \psi)^{2}(0.5 / 3.0)^{2}}} \approx 1.5
$$




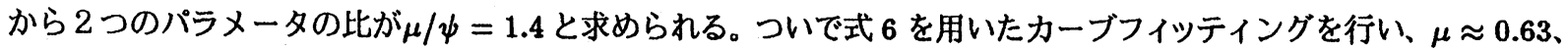
$\psi \approx 0.44$ が求められる。これらのパラメータから鈶直極限支持力を推定すれば $V_{M} \approx 1350[\mathrm{KN} / \mathrm{m}]$ で、支持力倸 数にして $N_{\gamma} \approx 16.7$ 程度であることを付記しておく。

以上のパラメータを用いて同定したマクロな破壊曲面と解析結果を $V-H$ 面上に表したのが図 9 である。図中の 曲線は上から順にそれぞれ $l_{H}=0.0,0.5,1.5,2.5,5.0[\mathrm{~m}]$ のケースを表す。また $V=375[\mathrm{KN} / \mathrm{m}]$ 面で切った $H-M / B$ 面上の破塤曲面を図 10 に示す。破壊曲面の形状は $H$ 軸方向に膨らんだ楕円で表されている。この破壊曲 面を用いることにより、さまさまな荷重条件下での見かけの摩擦倸数を評価することが可能である。また解析結 果から、ケーソンに作用する水平力作用高さが滑動に大きく影響を及ぼす因子であることが容易に理解される。

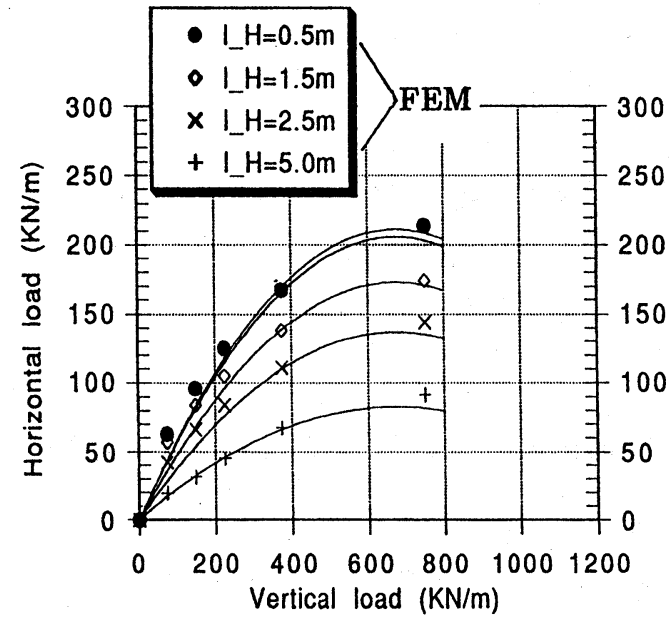

図 9. FEM 解析結果と同定した マクロな破壊曲面（ $V-H$ 面）

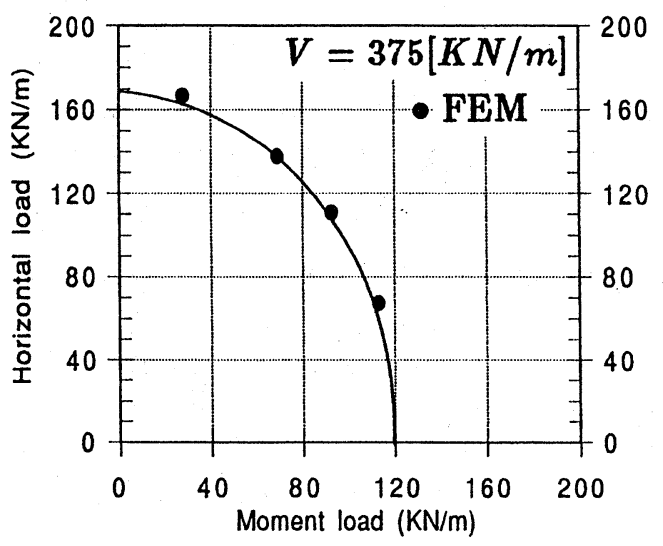

図 10. FEM 解析結果と同定した マク口な破壊曲面（ $H-M / B$ 面）

4. まとめ

従来、ケーソン式混成堤の設計に用いられている滑動安定計算では、見かけの摩搳保数として、先験的に得に 定数 $\tan \delta=0.6$ を用いて滑動抵抗を評価している。しかしながら、組合せ荷重を受ける浅い基礎の支持力問題と 捉えれば、見かけの摩擦保数が荷重状態に依存することを簡明に表現することが可能である。

捨石マウンドーケーソン系の支持力特性を評価するため、非線形有限要素法による解析を行った。解析結果は睡 往の実験結果と定性的によい一致を見た。また、これらの解析結果からマクロな破壊曲面を同定することにより、 さまさまな荷重条件における見かけの摩擦保数の評価が可能である。解析結果が定量的に一致しなかった原因と して、捨石マウンドの物性を適切に評価できていなかったことが挙げられる。

ケーソン式混成堤の滑動安定性を合理的に評価するためには、搭石マウンドーケーソン系の支持力特性を把握す るとともに、ケーソンに作用する外力、特に水平力の作用位置についても十分に考慮する必要がある。

今後の課題として、より精緻な地盤のモデル化、繰り返し塑性による摇れ込み沈下の検討、地盤-流体-構造物 系の相互作用の問題としての定式化などが挙げられる。

\section{Appendix ダイラタンシーと水平支持力の関係}

ダイラタンシーによる水平支持力の増加を要素の挙動から簡単に説明する。体積一定条件で単純せん断変形を 与えたときの塑性ひずみ速度円を図 A1 に示す。ダイラタンシー角 $\alpha$ のため面 S に対する塑性ひずみ速度は図中の A 点である。一方、破壊状態を考えると、応力円はMohr-Coulomb の破萝線に接しているので、塑性ひずみ速 度と応力の共軸性の仮定のもとで面 S に対する応力は図 A2 の B 点になる。面 S 上の主応力とせん断応力の比を $\eta=\sigma / \tau$ とすれば、ダイラタンシー角 $0 \leq \alpha \leq \varphi$ に対して $\sin \varphi \leq \eta \leq \tan \varphi$ となる。ケーソン直下の大部分の要 
素が単純せん断モードであれば、応力比 $\eta$ はおおよそ見かけの摩擦係数 $\tan \delta=H / V に$ 対応すると考えられる。

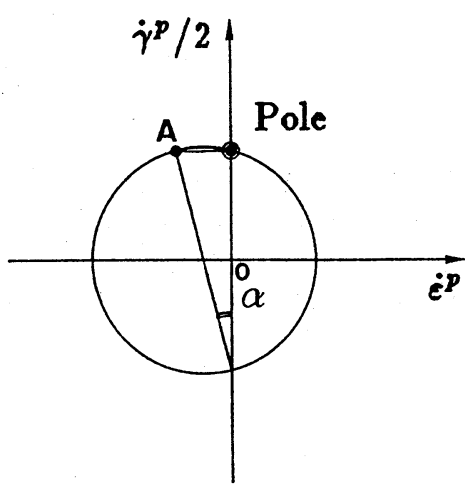

図A1. 単純せん断を受ける

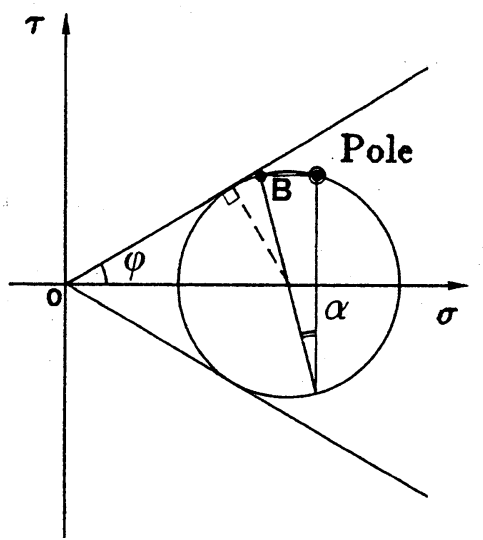

図 A2. 単純せん断を受ける要素の応力・図A3. 単純せん断を受ける要素 要素の塑性ひずみ速度

\section{参考文献}

[1] Nova, R. \& Montrasio, M. , "Settlements of shallow foundations on sand," Géotechnique 41, No. 2, pp. 243-256, 1991.

[2] 田中洋行 他, “捨石マウンドの均しと支持力の関係について,” 海洋開発論文集, 土木学会, Vol. 3, pp. 131-136, 1987.

[3] 小林俊一 他, “波力を受けるケーソン構造物の安定性に関する考察”” 海洋開発論文集, 土木学会, Vol. 8, pp. 81-86, 1992.

[4] J. A. M. Teunissen, "Analysis of Plasticity and Non-coaxiality in Geomechanis," Dissertation Delft Univ. , 1991.

[5] Nagtegaal, J. et al. , "On numerically accurate finite element solutions in the fully plastic range," Comp. Meth. Appl. Mech. Engng. Vol. 4, No. 2, pp. 153-177, 1974.

[6] Davis, E. H. \& Booker, J. R. , "The Bearing Capacity of Strip Footings from the Standpoint of Plasticity Theory," Proc. 1st Australia-New Zealand Conf. on Geomech., Vol. 1, pp. 276-282, 1971. 